\title{
黒潮と内部波が影響する 伊豆諸島周辺海域における流動場の解明
}

\author{
増永 英治 1 - 鈴江 洋太 $2 \cdot$ 内山 雄介 3 - 山崎 秀勝 4 \\ 1正会員 茨城大学助教 広域水圈科学教育研究センター（干316-8511茨城県日立市中成沢町4-12-1） \\ E-mail:eiji.masunaga.office@vc.ibaraki.ac.jp \\ 2 正会員 株式会社建設技術研究所 中部支社（一460-0003 愛知県名古屋市中区錦 1-5-13) \\ E-mail:yta-suzue@ctie.co.jp \\ 3正会員 神戸大学教授 大学院工学研究科市民工学専攻 (干 657-8501 兵庫県神戸市灘区六甲台町1-1) \\ E-mail:uchiyama@harbor.kobe-u.ac.jp \\ 4非会員 東京海洋大学教授 大学院海洋科学技術研究科( ⿳1 108-8477東京都港区港南4-5-7) \\ E-mail:hide@kaiyodai.ac.jp
}

\begin{abstract}
潮汐と内部潮汐が伊豆諸島周辺海域に及ぼす影響を評価するために, 潮汐の外力を組み込んだ領域海洋モ デルROMSを用いた解析を実施した。内部波のエネルギーフラックスを推定した結果, 伊豆諸島周辺では 非常に強い内部波が発生していることがわかった。内部波のエネルギーフラックスは潮汐によってバック グラウンドの值の10倍以上に増幅され，対象海域の内部波は潮汐によって支配されていることがわかった. また, 潮汐により運動エネルギー全体量は増大するが, 順圧的な運動エネルギーはむしろ減少し, 傾圧 （内部波）成分の運動エネルギーは増大していた。したがって, 対象海域では黒潮や風に比べ潮汐によっ て発生した傾圧的な流れを伴う内部波が流動場に対して卓越して影響していること, 内部潮汐が伊豆諸島 周辺海域の海水運動に強く寄与していることがわかった.
\end{abstract}

Key Words : internal tides, nonlinear internal waves, baroclinic motion,Izu-Ogasawara Ridge,

\section{1. はじめに}

沿岸海域において，潮汐波は傾圧的な内部潮汐を励起 させ密度場の擾乱を伴う非常に強い流れを発生させる. 内部潮汐によって発生する等水温面の振幅は100 mを超 える場合があり $(\text { Shea })^{1)}$ )、潮汐順圧流による流れの強さ の十倍を超える傾圧流を発生させる(Masunaga $5^{2)}$ ). 強い 内部潮汐は一般的に分散関係式で示される内部波のビー ム角と海底斜角が一致する海域や地形の起伏によって発 生する(Cacchione $ら^{3)}$, Alford $\left.5^{4}\right)$. 大陸棚で励起された内 部波は，浅海域もしくは深海域一伝搬し最終的に散逸す る.

大陸棚において発生した内部潮汐は, 浅海域の伝搬に 伴い非線形性を強めることがわかっている(Masunaga ${ }^{2)}$, Venayagamoorthy $5^{5}$ ). 非線形性を強めた内部潮汐は，海 底斜面上において非常に強い流れと乱流混合を発生させ ることが近年の研究により明らかとなった(Masunaga らの). 非線形性を強めた内部波は，強い物質輸送を伴い，沿岸 海域と外洋間の物質輸送を強化していると考えられてい る(Van Weering ら). また内部潮汐によって発生した物質 及ひ熱輸送は海洋生態系や地球規模の熱循環に密接に関 わっていると考えられている(Walsh $\left.{ }^{8}\right)$. しかしながら， 日本近海における内部波及び内部潮汐の発生機構やその
動態は未解明な点が多く, 詳細なメカニズムは明らかと なっていない.

日本本州南岸の海洋環境は, 潮汐流に加えて強流と暖 水を伴う黒潮に強い影響を受けている．黑潮により発生 する強い流れは，流速 $2 \mathrm{~m} / \mathrm{s}$ 超えることもあり，日本周 辺海域の海水運動に大きな影響を与えている．黑潮によ り発生した流れや渦が浅海域に現れると強い混合を伴う 流れが発生することが知られ, Hasegawaら 豆諸島を通過時に強い鉛直混合を発生させ物質輸送を強 化していることを明らかにした.

このような背景の中，本研究では潮汐と黒潮が影響す る伊豆諸島周辺海域における流動場を3次元海洋モデル JCOPE2-ROMSを用い, 対象海域における内部波の動態 を調査した。沿岸海域における詳細な流動場を調査する ためにJCOPE2-ROMSシステム (内山ら ${ }^{10)}$ ) を3段階ダウ ンスケーリングすることで，対象海域の水平解像度を $300 \mathrm{~m}$ まで向上させた. 内部潮汐が強化されると考えら れる夏季（2013年7月から8月）に着目し，潮汐による効 果を検証するために, 潮汐を外力として与えたモデルと 潮汐を外力として与えない2 个一スを比較し, 潮汐と内 部波によって発生する内部波エネルギーフラックス及び 運動エネルギーの解析を行った。 また, 潮汐によって強 化される渦運動エネルギーについても報告する. 


\section{2. 海洋モデル}

本研究ではJCOPE2再解析值を境界条件とした3段階ネ スティングを採用し，伊豆諸島周辺海域を水平解像度 300 mで解像するダウンスケーリング領域海洋モデル ROMSを用いた（図-1）。2段ネスティングL2領域（水 平解像度1 km）までの領域において2011年12月から2013 年6月までを潮汐エネルギーを与えない助走期間として 設定し，2013年7月からL2領域の海境界から潮汐を海面 高度の外力として与え, 同時に高解像度L3領域へダウ ンスケーリングを行った。潮汐外力にはTPXO7.2潮位モ デル值を用いたが，北西太平洋での再現性が低いため, ニュートン法を用いて伊豆大島岡田港の潮位観測データ にフィッティングするように補正を加えた．海面風応力 と海面放射・熱フラックスについては，気象庁GPVMSM再解析值とCOADS月平均気候值を外力としてそれ ぞれ用いた. 数值計算データの解析には, 潮汐を外力と して与えた後，20日間を潮汐助走期間として設定し， 2013年7月 21日から2013年8月 14日までの計算データを解 析に用いた. 過去の研究により, 本モデルは日本周辺海 域における物理現象及び解析に対する十分な精度が担保 されていることが示されている(例えば内山ら $\left.{ }^{11}\right)$ ．

潮汐を外力として海洋モデルに与える場合, 潮位変動 の再現性がモデル精度に大きな影響を与える，そこで伊 豆大島岡田港における主要4分潮 $\left(S_{2}, M_{2}, K_{l}, O_{l}\right)$ の振幅

表-1 伊豆大島岡田港における潮位の比較. 表内の差はモデ ルから観測值を差し引いた值を示す。

\begin{tabular}{cclc} 
& 振幅差 & 遅角差 & $R_{E}$ \\
\hline$S_{2}$ & $1.8 \mathrm{~mm}$ & $1.27^{\circ}$ & $8.2 \%$ \\
\hline$M_{2}$ & $-17.1 \mathrm{~mm}$ & $1.70^{\circ}$ & $1.6 \%$ \\
\hline$K_{1}$ & $-29.8 \mathrm{~mm}$ & $1.96^{\circ}$ & $8.9 \%$ \\
\hline$O_{1}$ & $-7.9 \mathrm{~mm}$ & $-5.13^{\circ}$ & $7.0 \%$ \\
\hline
\end{tabular}

と遅角の比較をした（表-1）。また下記式（1）と（2） から観測值と比較した潮位の変動の相対RMSエラー值 $\left(R_{E}\right)$ を求めた（Carterら $\left.{ }^{12}\right)$.

$$
\begin{gathered}
R_{E}=\frac{E}{A_{O}} \\
E=\sqrt{\frac{1}{2}\left(A_{O}^{2}+A_{M}^{2}\right)-A_{O} A_{M} \cos \left(G_{O}-G_{M}\right)}
\end{gathered}
$$

$A$ は振幅， $G$ は遅角， $O$ と $M$ はそれぞれ観測值とモデルの 值であることを示す． $R_{E}$ は8.9\%以下を示し，主要4分潮

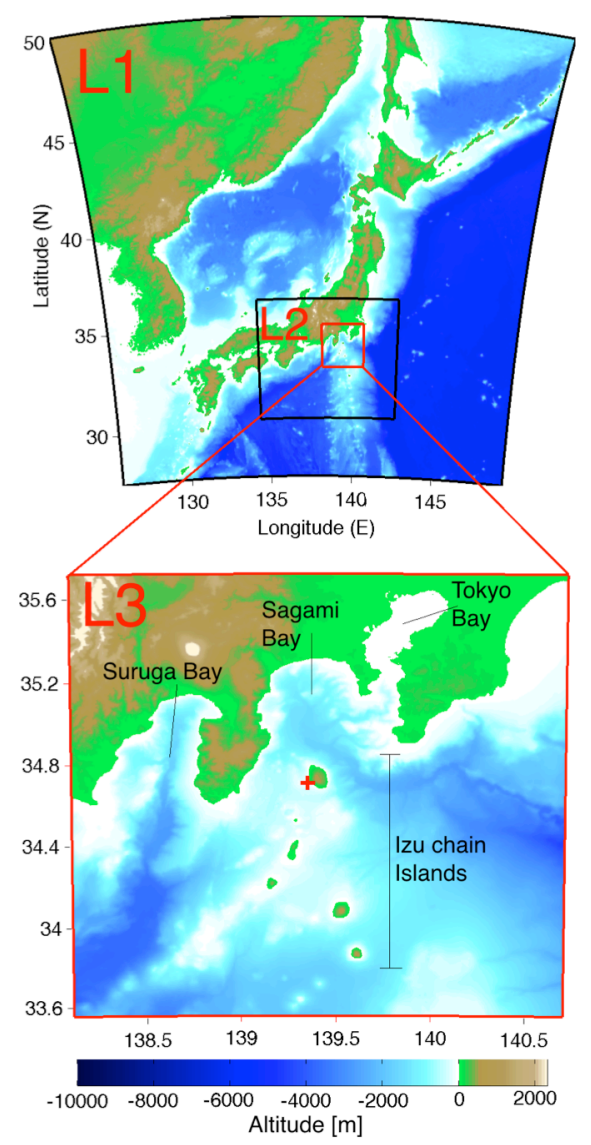

図-1３段ネスト海洋モデルROMSの計算領域

(a) 1
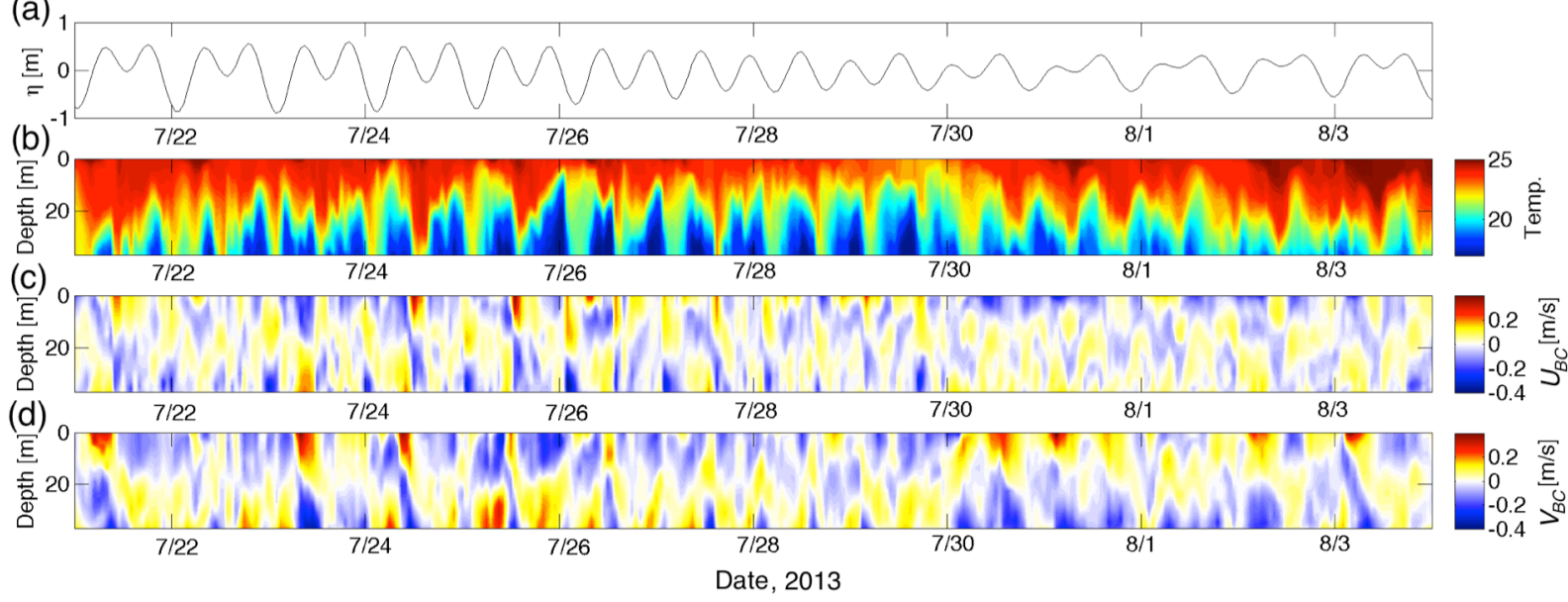

図-2 伊豆大島西側(図-1 L3領域中の赤十字点)における(a)潮位，(b)水温，(c)東西と(d)南北方向の傾圧成分 $\left(U_{B C}\right.$ 及び $\left.V_{B C}\right)$ の流速の 鉛直時系列図(2013年7月21日～8月3日). 
(a)

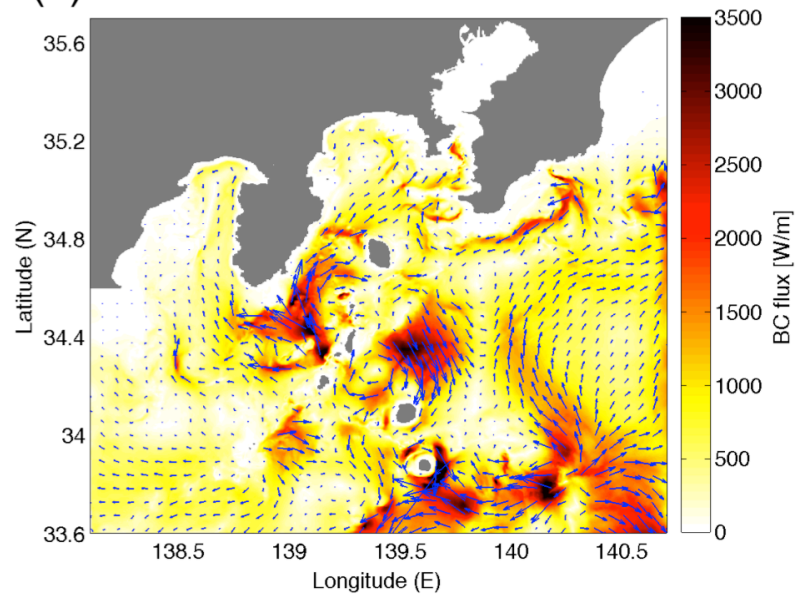

(b)

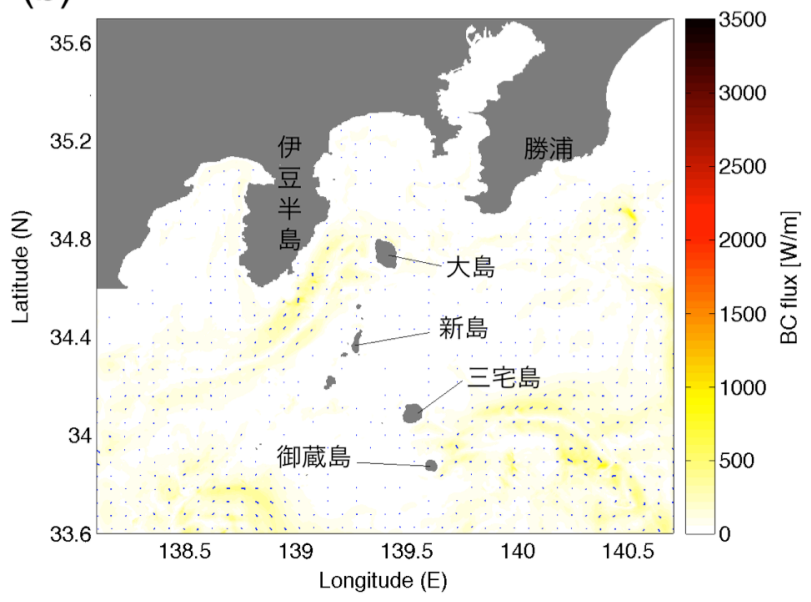

図-3 (a) 潮汐を外力として与えたモデル結果から推定した内部波エネルギーフラックスと(b) 潮汐を外力として与えていないモデ ル結果から推定した内部波エネルギーフラックス

の平均値は6.4\%であった. よって領域モデル内におけ る潮位変動は数\%の誤差内において良好に再現できてい ると言える.

\section{3. 内部潮汐}

伊豆大島西側水深 $40 \mathrm{~m}$ 地点の潮位，水温，傾圧流速 成分を図-2に示す．図-2 (c, i) に示している傾圧流速は, 流速から鉛直平均した流速を差し引いた流速であり, 内 部潮汐による傾圧的な運動成分を示している. 水温 $20^{\circ} \mathrm{C}$ 以下の冷水が低層から遡上し浅海域に断続的に現れ，冷 水の遡上と同時に流速 $0.4 \mathrm{~m} \mathrm{~s}^{-1}$ を超える強い傾圧流が発 生していた。 このような強い冷水の遡上は, 潮汐を外力 として与えていないモデルでは確認されなかった，その ため, 図-2に見られるような大きな等水温面の変動を伴 う冷水の伝搬は, 潮汐により励起された内部潮汐によっ て引き起こされたと考えられる. 内部潮汐に伴う水温の 変動は複雑な構造を示し, 線形的な潮位変動から大きく 離れ，周期も一致していない。このような沿岸海域で複 雑な構造を伴う内部波は, 非線形性内部波もしくは internal bores と呼ばれ頻繁に海洋において観測される (Masunaga $5^{2}$ ).

領域内における内部波の伝搬動態を定量的に調査する ために, 鉛直積分した内部波エネルギーフラックス $\left(F_{E}\right)$ を下記式より求めた $\left(\operatorname{Kang} ら^{13}\right)$.

$$
F_{E}=\int_{z}^{\eta} \mathbf{u}_{B C}^{\prime} p^{\prime} d z
$$

ここで， $\mathbf{u}_{\mathrm{BC}}$ は対象周期の傾圧流速， $p$ 'は対象周期の圧 力変動である. 半日 $\left(S_{2}, M_{2}\right)$ から 部波に着目するために，3日間より短い周期の成分を八 イパスフィルターによって求め, 内部波のエネルギーフ ラックスとした. 潮汐を外力として与えたケースのエネ ルギーフラックスとフラックス発散の大潮小潮周期（7 月21日から14日間）の時間平均值を図-3(a)に示す．伊 豆諸島周辺海域では, $3 \mathrm{~kW} / \mathrm{m}$ を超える強いエネルギー フラックスが確認された. 特に強い内部波エネルギの発 生・増幅は新島の西及び東側の海域と御蔵島の南東海域 で見られた．新島西側で発生した内部波は伊豆半島及び 大島に伝搬し, 新島東側で発生した内部波は三宅島方向 一伝搬していた. 御蔵島南東海域で発生した内部波は複 杂隹な伝搬構造をしているが, 概ね御蔵島南東から御蔵島 方向一伝搬していた。これらの強い内部波は, 順圧的な 潮汐波が浅い伊豆海嶺を伝搬するときに地形の効果を受 け傾圧的な運動を伴う内部潮汐にエネルギーが変換され るためであると考えられる. 伊豆諸島周辺以外の東京湾 湾口や房総半島勝浦沖においても強い内部波の発生が確 認できるが，フラックスの強さは伊豆諸島周辺に比べて 弱い.

潮汐を外力として与えないケース(図-3(b))では，内部 波エネルギーフラックスは計算領域全体で $0.5 \mathrm{~kW} / \mathrm{m}$ 以 下の值を示し，潮汐を考慮した計算の場合に比べ10倍程 度低い值を示した. 潮汐以外の内部波を励起させる要因 として, 風によって発生する内部波や地球自転による近 慣性周期内部波が考えられる（例えばIgeta ${ }^{14}$ ) 。対象 海域における慣性周期は20時間程度であるため, 図-3に 示した内部波フラックスには近慣性周期の内部波が含ま れる. しかしながら, 潮汐以外の外力によって発生する 内部波の強さは内部潮汐に比べて非常に弱く, 伊豆諸島 周辺では潮汐が内部波場を支配していることがわかった。

\section{4 運動エネルギー}

海水の運動エネルギーは以下のように順圧成分 $\left(K E_{B T}\right)$ と傾圧成分 $\left(K E_{B C}\right)$ に分けることが可能である $\left(K a n g ~^{13}\right)$.

$$
K E_{B T}=\frac{1}{2} \rho\left(U^{2}+V^{2}\right)
$$




$$
K E_{B C}=\frac{1}{2} \rho\left(u_{B C}^{2}+v_{B C}^{2}+w^{2}\right)
$$

ここで $\rho$ は密度， $U, V$ は順圧成分流速， $u_{B C}, v_{B C}$ は傾圧成分 の流速，wは鉛直流速である.内部波エネルギーフラッ クス同様に鉛直積分（全水深）及び14日間で時間平均し た全運動エネルギー密度，順圧成分の運動エネルギー密 度, 傾圧成分の運動エネルギ一密度及び, 潮汐の有無に よる運動エネルギーの比を図-4に常用対数スケールで表 す. 運動エネルギーの比は潮汐ありのケースでの值を潮 汐なしの場合の值で除した值とした。潮汐を外力として 与えたケースでは，新島の南北の海域において運動エネ ルギ一密度 $1 \times 10^{2} \mathrm{~J} \mathrm{~m}^{-3}$ を超える非常に強い海水運動が発 生し，潮汐を考慮しないモデルに比べて10倍以上のエネ ルギーであった．潮汐により運動エネルギーが大きく増 大している海域では，黒潮による流れや風による効果に 比べ潮汐が流動場に卓越して影響していると言える. 特 に新島の北西側の海域では，運動エネルギーが潮汐によ り20倍以上増加している海域が存在していた.

潮汐により運動エネルギーが強化されている領域のう ち, 伊豆諸島の岸に近い海域では順圧成分の運動エネル ギーの増大が大きい（図-4(h)）。これは順圧的な潮汐 波が浅い伊豆海嶺を通過する時に生じる強い海水運動に 起因すると考えられる. 一方，岸近くでは傾圧的な運動 エネルギーは順圧成分ほど潮汐により増加していないが, 岸から離れたより広い海域において運動エネルギーが増 大しており，順圧成分の傾向と一致しない（図一 4(h,i)). 傾圧的な運動エネルギーは主に内部波によっ て増幅されるため, 潮汐によって沖合で励起された内部
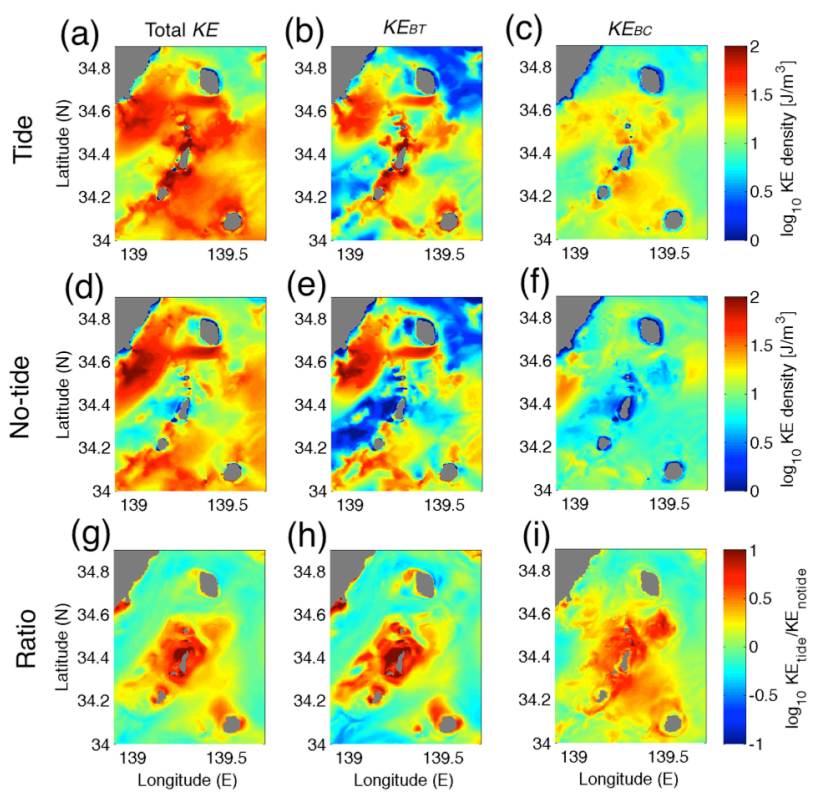

図-4 伊豆諸島周辺の運動エネルギ一密度. ( $a, b, c)$ 潮汐を外力 として与えたケース, $(\mathrm{d}, \mathrm{e}, \mathrm{f})$ 潮汐を外力として与えてい ないケース, (g, h, i) 潮汐の有無による運動エネルギーの 比. $(\mathrm{a}, \mathrm{d}, \mathrm{g})$ 全成分, $(\mathrm{d}, \mathrm{e}, \mathrm{f})$ 順圧成分, $(\mathrm{g}, \mathrm{h}, \mathrm{i})$ 傾圧成分
波や岸近くで励起された内部波が伝搬することで広い海 域の海水運動に影響を及ぼしていると考えられる.

潮汐による運動エネルギーの変化をより詳細に調査す るために，伊豆諸島周辺海域（図-4内に示す海域）にお ける $100 \mathrm{~m}$ 海底水深毎の運動エネルギーの空間積分值, 積分值の潮汐の有無による比, 海底水深に対する累積運 動エネルギー（いずれも時間平均值）を求めた（図-5）。 水深毎の全運動エネエルギーは，水深500 m程度までは 潮汐により増加しているが，それ以下の水深では潮汐に よる変化はほとんど見られなかった。また全水深帯で積 分した全運動エネルギーの潮汐の有無による違いは非常 に小さい（図-5(e)）。よって潮汐が外力として加わる ことにより, 岸に近い浅い海域では運動エネルギーが増

(a)

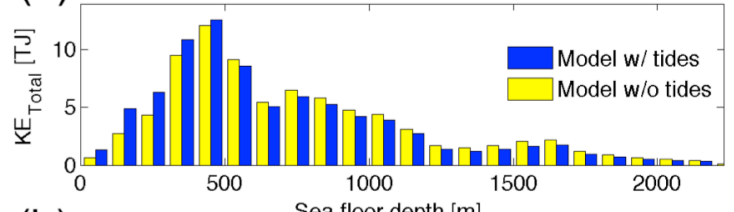

(b)

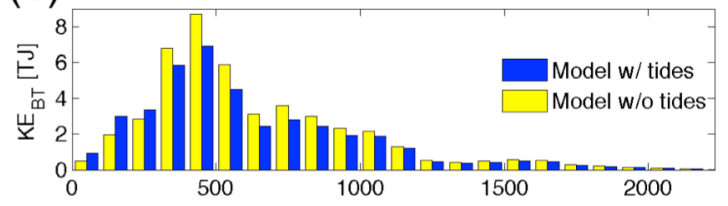

(c)

Sea floor depth $[\mathrm{m}]$

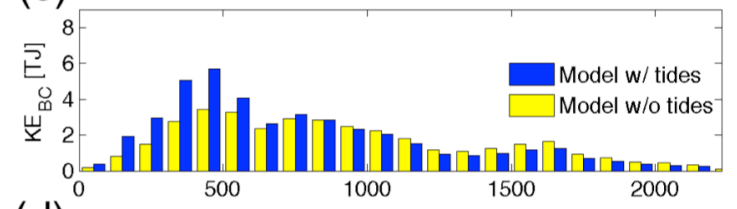

(d)
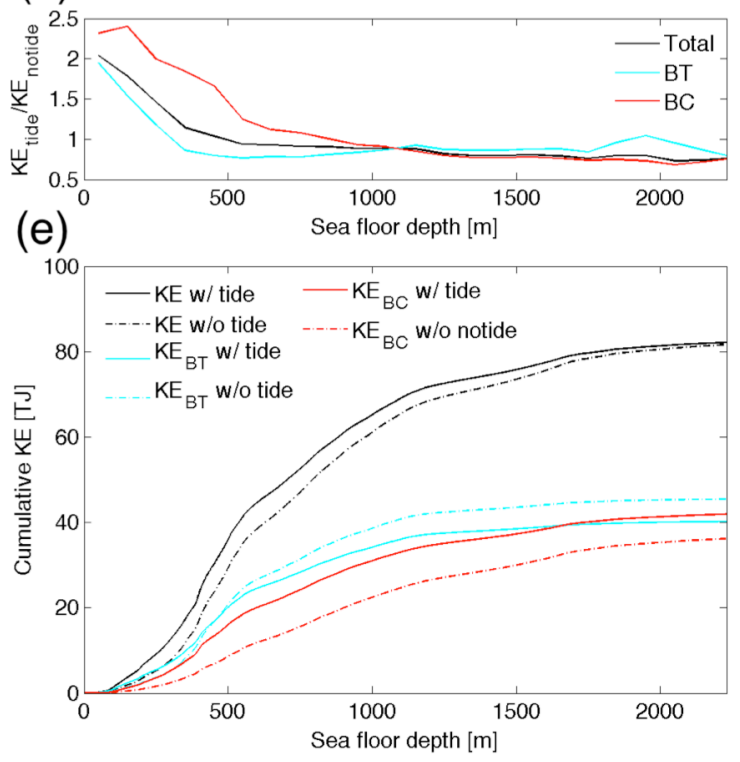

図-5 伊豆諸島周辺海域において $100 \mathrm{~m}$ 海底水深毎に積分した （a）全運動エネルギー，（b）順圧成分の運動エネル ギー，（c）傾圧成分の運動エネルギーと（d）潮汐の 有無による運動エネルギーの比.（e）は海底水深に対 し累積した運動エネルギーを示す 
(a)

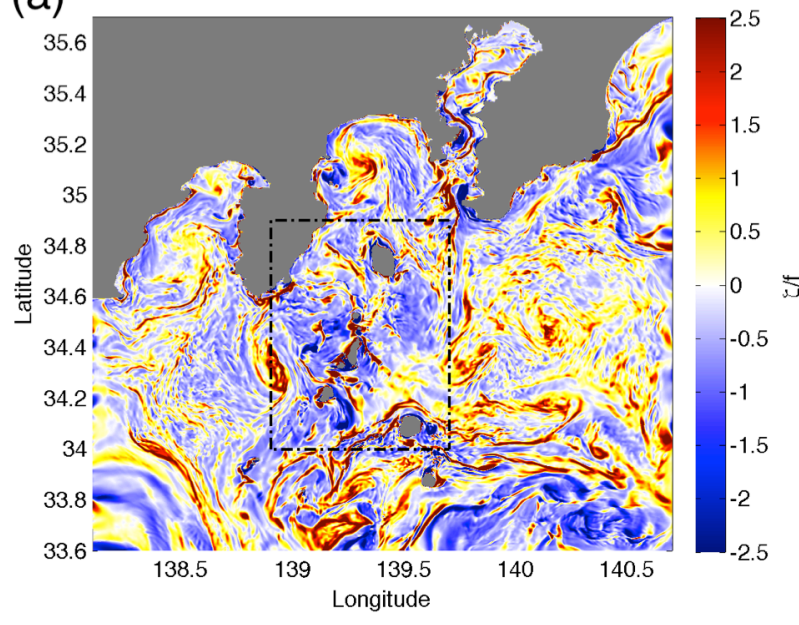

図-6２013年7月24日4:00における(a)海面の相対渦度(乡/f) のスナップショット ンストロフィーの時系列

加し，岸から離れた沖合の深い海域では減少していたと 言える. 順圧成分の運動エネルギーは, 水深 $300 \mathrm{~m}$ まで の海域では潮汐による増加が現れているが，水深 $500 \mathrm{~m}$ 程度の海域ではエネルギーが減少していた。 内部波によ り強く影響される傾圧成分の運動エネルギーは，水深 $500 \mathrm{~m}$ 程度の海域まで潮汐による増加が大きく, 増加率 は順圧成分に比べて大きかった。岸から水深500 m程度 の海域までの累積運動ネルギーは, 内部波による傾圧成 分が2倍程度に増加していた。一方順圧成分は, $500 \mathrm{~m}$ 水 深までの累積值にほとんど変化はなく, $500 \mathrm{~m}$ 以深まで の海域の累積值は潮汐により運動エネルギーが低下して いた．以上のことから，海底水深500 $\mathrm{m}$ 程度の海域では, 潮汐のエネルギーの多くは傾圧的な海水運動に変換され 内部潮汐として伝搬していると言える。 このことは図一 3 (a)において内部波エネルギーフラックスの強い部分 が接岸した海域ではなく沖合側で強いことと一致する.

累積した順圧成分の運動エネルギーが低下寸る要因と して, 潮汐波により黒潮などによって発生する流れが潮 汐により減衰される，若くは潮汐波により順圧成分から 傾圧成分一のエネルギー変換が強化されるのではないか と考えられる. 潮汐によるな順圧成分の減衰メカニズム の詳細の解明は今後の課題である.

\section{5. 渦運動エネルギー}

海洋内におけるサブメソスケールスケール（数 $\mathrm{km}$ ～ 数十 $\mathrm{km}$ 程度) の渦運動は, 物質や熱輸送に大きく影響 していると言われている（例えばKamidairaら ${ }^{15}$ ) 。特に 日本本州南岸の海域では, 黒潮の影響により渦運動が活 発であると言われている $\left(\mathrm{Ma} 5^{10}\right)$ ．海表面における相 対渦度から対象海域では, 数 $\mathrm{km}$ スケールの複雑な渦構 造が現れていた（図-6(a)）。伊豆諸島の周辺海域（図一 る. (b)

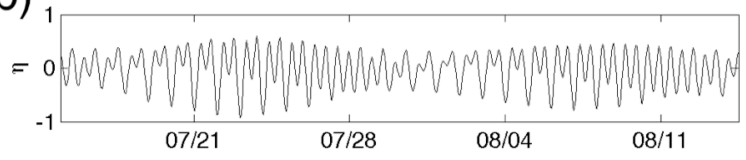

(c)

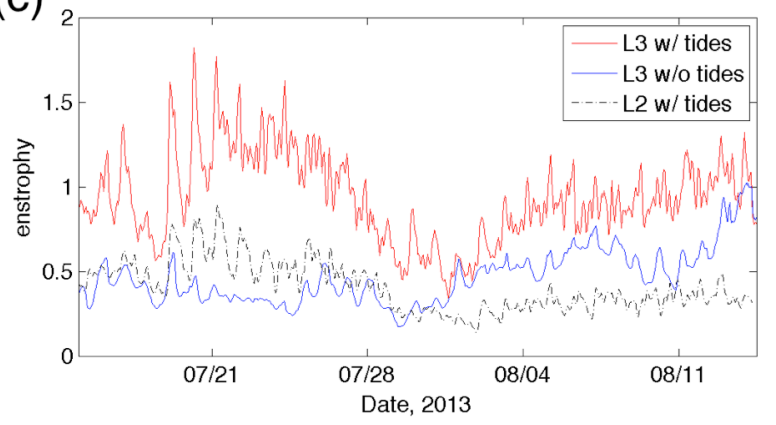

（b）潮位，（c）伊豆諸島周辺海域における渦運動工

6(a))内の黒破線で囲まれた海域) における海面の渦運 動エンストロフィーを図-6 (c) に示す。潮位差が大きい7 月21日から28日の期間において, 潮汐の効果により渦運 動エネルギーが2〜3倍上昇していた．潮位差が小さい小 潮の時期（7月31日前後）では潮汐のによる効果は非常 に小さかった. 以上のことから潮汐により伊豆諸島周辺 では渦運動が活性化し, 渦運動による物質と熱の移流及 び拡散が促進されていると考えられる.8月4日以降潮汐 を外力として与えていないモデル結果におけるエンスト ロフィーの増大は, 黒潮が伊豆諸島により接岸していた ためである.

海洋モデルにより再現される渦構造は, 計算領域の解 像度に大きく左右される. 一般的に解像度が高いほど渦 運動が精度良く再現され, 強い渦運動が再現される. 高 解像度L3領域にダウンスケーリングを行っていないL 2 領域（水平解像度 $1 \mathrm{~km}$ ) のモデル結果から見積もった渦 運動エンストリフィーは，L3モデルの值のおおよそ半 分程度であった. よってダウンスケーリングの効果が対 象領域の渦運動エネルギーの再現に強く影響し, 渦運動 の再現には水平解像度 $300 \mathrm{~m}$ 以上の解像度が求められる と言える. 一方でL2 とL 3の2 領域で計算された内部潮汐 フラックスの強さは同様な值であったため, 内部潮汐の 再現という観点では水平解像度 $1000 \mathrm{~m}$ 程度で十分と言え

\section{6. 結論}

潮汐を外力として考慮した高解像度JCOPE2-ROMS 3段 階ダウンスケーリング領域海洋モデルによる計算・解析 の結果から以下のことが明らかとなった。

（1）伊豆諸島周辺海域では, 地形と潮汐の効果により強 
い傾圧流を伴う内部潮汐が発生していた。

(2) 潮汐によって発生する内部波は, バックグランドの 内部波エネルギーフラックスを10倍程度増大させ， 対象海域の内部波場を支配していた。

（3）潮汐の効果により伊豆諸島沿岸の運動エネルギーは 10倍程度増加し, 黑潮, 風による効果に比べ潮汐が 卓越して流動場に影響していた。

（4）順圧成分の運動エネルギーは，潮汐の効果により岸 近くの浅い海域では大きく増大していた。一方, 海 底水深が500 mよりも深い沖合の海域では順圧成分 のエネルギーが減少し，対象海域全体での累積の順 圧成分運動エネルギーは潮汐により減少していた.

(5) 傾圧成分の運動エネルギーは，潮汐により内部波が 沖合で励起もしくは伝搬するため，岸から離れた海 底水深 $500 \mathrm{~m}$ 前後の海域において大きく増大してい た.

(6) 潮汐により伊豆諸島周辺の渦運動エネルギーが数倍 程度大きくなることがわかった。

謝辞 : 本研究は, JST-CREST「海洋生物多様性および生 態系の保全・再生に資寸る技術基盤の創出」領域（代表 者: 山崎秀勝, グラントナンバー : JPRMJCR12A6）の補 助を受けた.

\section{参考文献}

1) Shea, R. E., Broenkow, W.W.: The role of intemal tides in the nutrienten richment of Monterey Bay, California. Estuarine Coastal and Shelf Science., Vol. 15, pp. 57-66, 1982.

2) Masunaga, E., Homma, H.,Yamazaki, H., Fringer, O., Nagai, T., Y. Kitade, Y. and Okayasu A.: Mixing and sediment resuspension associated with internal bores in a shallow bay, Continental Shelf Research, Vol. 110,pp. 85-99, 2015.

3) Cacchione, D.A., Pratson, L.F., Ogston, A.S.: The shaping of continental slopes by internal tides. Science, Vol. 296, pp. 724-727, 2002.

4) Alford, M. H., et al.,; The formation and fate of internal waves in the South China Sea, Nature, Vol. 521, pp. 65-69, 2015.

5) Venayagamoorthy, S.K., Fringer, O.B.: Numerical simulations of the interaction of internal waves with a shelf break, Physics of Fluids, Vol. 18, DOI:10.1063/1.2221863, 2006.

6) Masunaga, E., Fringer, O.B., Yamazaki, H., Amakasu, K.,: Strong turbulent mixing in duced by internal bores interacting with tidedriven vertically-sheared flow, Gephysical Research Lettters , DOI: 10.1002/2016GL067812., 2016.

7) Van Weering, T.C.E., De Stigter, H.C., Balzer, W., Epping, E.H.G., Graf, G., Hall, I.R., Vangriesheim, A.: Benthic dynamics and carbon fluxes on the NW European continental margin. Deep Sea Research Part II: Topical Studies in Oceanography, Vol. 48.,pp. 3191-3221, 2001.

8) Walsh, J. J.: Importance of continental margins in the marine biogeochemical cycling of carbon and nitrogen, Nature, Vol. 350, pp. 53-55, 1991.

9) Hasegawa, D., Yamazaki, H., Lueck, R.G. and Seuront, L.: How islands stir and fertilize the upper ocean, Geophysical research letters, Vol. 31(16), 2004.

10) 内山雄介, 石井翔太, 宮澤泰正 : JCOPE2-ROMS 多 段ネスティングによる黒潮続流域でのダウンスケー リング効果の検証, 土木学会論文集 B2(海岸工学), Vol. 66, No. 2, pp I_436-I_440, 2012.

11) Uchiyama, Y., Suzue, Y. and Yamazaki, H.: Eddy-driven nutrient transport and associated upper-ocean primary production along the Kuroshio, Journal of Geophysical Research Oceans, Vol. 122, DOI: 10.1002/2017JC012847.

12) Carter, G. S., and Gregg .M. C.: Intense, variable mixing near the head of Monterey Submarine Canyon, Journal of Physical Oceanography, Vol. 32, pp. 3145-3165. 2002.

13) Kang, D., and Fringer, O.,; Energetics of barotropic and baroclinic tides in the Monterey Bay area. J. Phys. Oceanogr., 42(2), 272-290, 2012.

14) Igeta, Y., Kumaki, Y., Kitade, Y., Senjyu, T., Yamada, H., Watanabe, T., Katoh, O. and Matsuyama, M.: Scattering of near - inertial internal waves along the Japanese coast of the Japan Sea, Journal of Geophysical Research: Oceans, Vol. 114 (C10), 2009.

15) Kamidaira, Y., Uchiyama, Y. and Mitarai, S.: Eddy-induced transport of the Kuroshio warm water around the Ryukyu Islands in the East China Sea. Continental Shelf Research, 2016, https://doi.org/10.1016/j.csr.2016.07.004.

16) Ma, X., Chang, P., Saravanan, R., Montuoro, R., Hsieh, J.S., Wu, D., Lin, X., Wu, L. and Jing, Z: Distant Influence of Kuroshio Eddies on North Pacific Weather Patterns?. Scientific reports, .Vol. 5, DOI: 10.1038/srep17785, 2015.

(2017.3.15 受付)

\title{
A STUDY OF FLOW FIELD INFLUENCED BY INTERNAL TIDES AND THE KUROSHIO AROUND THE IZU-CHAIN ISLANDS
}

\author{
Eiji MASUNAGA, Yota SUZUE, Yusuke UCHIYAMA and Hidekatsu YAMAZAKI
}

Regional Oceanic Numerical simulations using ROMS with tidal forcing were conducted to investigate tidally induced internal waves (internal tides) in the vicinity of the Izu-chain Islands. The tides enhance the enrgy flux of internal waves by about 10 times as large around the islands. Therefore, in the study region, the internal waves are considerably enargized by the tidal forcing. Although the total and baroclinic components of kinetic eneygy increase due to the tides, the barotropic kinetic energy component decreased by the tidal forcing. The internal waves accompanied by strong baroclinic flows largely contribute to the flow compared to the currents due to winds and the Kuroshio. The numerical simulateons also revealed the enhanced eddy motiions due to the tidal forcing, suggesting that the tides contiribute to lateral mixing or transports via meso- and submesoscale eddies. 